\title{
Special issue: future 4 butterflies in Europe
}

\author{
John W. Dover ${ }^{1}$
}

Published online: 8 June 2017

(C) Springer International Publishing Switzerland 2017

In 1989 the first meeting entitled 'The Future of Butterflies in Europe' was held at The Agricultural University in Wageningen, The Netherlands (Pavlicek-van Beek et al. 1992). I was lucky enough to attend that splendid meeting and the Proceedings volume still has a pride-of-place on my bookshelf. The meeting has been reconvened over the years, but as far as I am aware no further volume of papers was ever produced. We have published the proceedings of Butterfly Conservation UKs Symposia in the Journal of Insect Conservation over the years, starting with the very first volume of the Journal back in 1997, and most recently in 2011 and 2015 (from the 2010 to 2014 meetings respectively) and we are now pleased to be able to present a selection of papers from the fourth 'Future of Butterflies in Europe' meeting at Wageningen. This meeting was held from 31st March to 2nd April 2016 and organised by Michiel WallisDeVries, Chris van Swaay and Irma Wynhoff.

Of the eight papers in this Special Issue, five are on various aspects of the Phengaris/Maculinea group of butterflies. Timus et al. (2017) explored source-sink dynamics for Phengaris nausithous and Phengaris teleius in central Transylvania, Romania. Wynhoff et al. (2017), also working on P. teleius, explored the impact of fen meadow restoration via a LIFE+ project in the Netherlands using the interesting approach of using transplanted fen sods from mature meadows as a way of facilitating host ant colonisation. Vrabec et al. (2017) examined the potential impact of a waterway development on populations of P. teleius and

John W. Dover

j.w.dover@staffs.ac.uk

1 The Science Centre, Staffordshire University, Leek Rd, Stoke-on-Trent ST4 2DF, UK
P. nausithous in the Czech Republic whilst Popović et al. (2017) report on studies in Serbia on P. teleius, where it is at the edge of its northern European distribution. Finally, Osváth-Ferencz et al. (2017) examined the population demography of Phengaris arion in four European countries (Italy, Romania, Poland and Hungary).

The three remaining papers cover different aspects of butterfly conservation. Munguira et al. (2017) addressed the development of management plans for the four endangered Spanish endemics Polyommatus violetae, Polyommatus golgus, Agriades zullichi, and Euchloe bazae. Essens et al. (2017) analysed the vulnerability of 397 of the 482 European species by incorporating data on life-history and climate niche traits in vulnerability analyses. They concluded that mobility, development rate, and overwintering stage traits were preferable to using the generalist-specialist axis to identify vulnerable species. Vantieghem et al. (2017) analysed the quality of citizen science data using skipper butterflies. Such data provide a substantial and important component of distribution mapping, but misidentification of species can have important consequences. In their study system of three skippers, Ochlodes sylvanus, Thymelicus lineola and Thymelicus sylvestris, they demonstrated that misidentifications of the latter species resulted in an overestimation of its distribution and concluded that strong quality control checks were needed in the use of such data.

I'm sure that you will find much of interest in these papers, and I look forward to the next meeting in Wageningen in 2020 !

\section{References}

Essens T, van Langevelde F, Vos RA, Van Swaay CAM, WallisDeVries MF (2017) Ecological determinants of butterfly 
vulnerability across the European continent. J Insect Conserv. doi:10.1007/s10841-017-9972-4

Munguira ML, Barea-Azcón JM, Castro-Cobo S, García-Barros E, Miteva S, Olivares J, Romo H (2017) Ecology and recovery plans for the four Spanish endangered endemic butterfly species. J Insect Conserv. doi:10.1007/s10841-016-9949-8

Osváth-Ferencz M, Bonelli S, Nowicki P, Peregovits L, Rákosy L, Sielezniew M, Kostro-Ambroziak A, Dziekańska I, Kőrösi Á (2017) Population demography of the endangered large blue butterfly Maculinea arion in Europe. J Insect Conserv. doi:10.1007/ s10841-016-9944-0

Pavlicek-van Beek T, Ovaa AH, van der Made JG (1992) Future of Butterflies in Europe. Department of Nature Conservation. Agricultural University, Wageningen

Popović M, Šašić M, Medenica I, Šeat J, Đurđević A, CrnobrnjaIsailović J (2017) Living on the edge: population ecology of Phengaris telius in Serbia. J Insect Conserv. doi:10.1007/ s10841-016-9922-6
Timus N, Czekes Z, Rakosy L, Nowicki P (2017) Conservation implications of source-sink dynamics within populations of endangered Maculinea butterflies. J Insect Conserv. doi:10.1007/ s10841-016-9906-6

Vantieghem P, Maes D, Kaiser A, Merckx T (2017) Quality of citizen science data and its consequences for the conservation of skipper butterflies (Hesperiidae) in Flanders (northern Belgium). J Insect Conserv. doi:10.1007/s10841-016-9924-4

Vrabec V, Kulma M, Bubová T, Nowicki P (2017) Long-term monitoring of Phengaris (Lepidoptera: Lycaenidae) butterflies in the Přelouč surroundings (Czech Republic): is the waterway construction a serious threat? J Insect Conserv. doi:10.1007/ s10841-017-9982-2

Wynhoff I, Kolvoort AM, Bassignana CF, Berg MP, Van Langevelde F (2017) Fen meadows on the move for the conservation of Maculinea (Phengaris) teleius butterflies. J Insect Conserv. doi:10.1007/s10841-016-9941-3 